На основе полученных данных, наша гипотеза, где мы предполагали, что существуют значимые различия в эмоциональных состояниях у студентов, состоящих и не состоящих в романтических отношениях, а именно у студентов, состоящих в отношениях, преобладает ощущение комфортности, они не склонны испытывать депрессивные состояния, а также ощущают одиночество в меньшей степени, не подтвердилась.

$$
* * *
$$

1. Авдеев Д. А Уныние и депрессия./ Д. А. Авдеев // Сходства, различия, врачевание. 3-е изд. доп. и перераб. - Москва: «МБЦ прп. Серафима Саровского», «Омега», 2011. - 5 с.

2. Боковиков А. М. Энциклопедия глубинной психологии : учебное пособие / А. М. Боковиков // Последователи 3. Фрейда // Пер. с нем. - Москва: «Когито-Центр», МГМ, 2002. - 190-197 с.

3. Болотова А. К. Психология развития: учебное пособие / Под ред. А. К. Болотовой и О. Н. Молчановой. - Москва, 2005. - 106-111 с. - Режим доступа: http://pedlib.ru/Books/1/0062/1_00621.shtml\#book_page_top

4. Бурно. М. Е. О характерах людей / М. Е. Бурно // Изд. 3-е, испр. и доп. Москва: Академический Проект; Фонд «Мир», 2008. - 639 с.

5. Григорьева М. Н. Психологические особенности Я-концепции личности юношеского возраста с асоциальной направленностью / М. Н. Григорьева // Диссертация и автореферата по ВАК РФ Оренбург - 2007. - 263 с. - Режим доступа: https:/www.dissercat.com/content/psikhologicheskie-o..

6. Губина Н. В. Уровень проблемной жизни как показатель социального тонуса / Н. В. Губина // Социологические исследования. - 2006. -Т. 1., № 9. - С. 122-126

7. Долгова Ю. Н. Субъективное благополучие личности в контексте жизненной стратегии / Ю. Н. Долгова // Личность, семья и общество: вопросы педагогики и психологии. СПб.: Санкт Петербург, 2013. - Вып. 32. - С. 75-79

8. Емчик О. А Романтическая привязанность и стиль любви у студентов университета / О. А. Емчик // Психологические исследования: сб. научн. трудов. Под ред. А. Л. Журавлева, Е. А. Сергиенко. Москва: Издательство «Институт психологии ран», 2008. - Вып. 3 - С. 114-128

9. Изард К. Э. Психология эмоций / К. Э. Изард; перев. с англ., - СПб: Издательство «Питер», 2012. $464 \mathrm{c.}$

10. Куликова Л. Н. Проблемы саморазвития личности / Л. Н. Куликова - Хабаровск, 1997. - 315 с.

11. Крейн У. Теории развития. Секреты формирования личности / У. Крейн // 5-е междунар. изд. СПб.: Прайм-ЕВРОЗНАК, 2002. - 71 с.

12. Кон И. С. Ребенок и общество: учебное пособие / И. С Кон - Москва, "Академия", 2003. - 59-68 с.

13. Крюкова Т. Л. Психология семьи: жизненные трудности и совладение с ними / Т. Л. Крюкова СПб., Речь, 2005. - 107 - 109 с.

14. Кьеркегор С. Заключительное не научное послесловие к «Философии краха»/С. Кьеркегор // Логос, 1997. - № 10. С. 139 - 147

15. Леонтьев А. Н. Потребности, мотивы и эмоции / А. Н. Леонтьев // Издательство Московского Университета, $1971-9-10$ с.

16. Маклаков А. Г. Общая психология: учебник для вузов / А. Г. Маклаков // СПб.: Санкт - Петербург, 2016. - 401- 403c., 412 c.

17. Мясищев В. Н. Психология отношений / В. Н. Мясищев // Избр. Психолог. Труды Москва: Ин - т практич. Психологии: Воронеж НПО МОДЭК, 1995 - Режим доступа: https://cyberleninka.ru/article/n/analiticheskiy-obzor-issledovaniy-nevernosti-i-izmeny-v-romanticheskihotnosheniyah/viewe

18. Немов Р. С. Психология: учебное пособие / Р. С. Немов // Общие основы психологии 4-е издание. Москва: ВЛАДОС, 2003 - Кн. 1, 436 - 456 с.

19. Нуллер Ю. Л. Депрессия и деперсонализация / Ю. Л. Нуллер// Медицина Москва, 1981 - 207 с.

\title{
Simonovich N.E. \\ The study of people's social well-being: meaningful characteristics and referents
}

Russian State Humanitarian University (Russia, Moscow)

doi: 10.18411/lj-02-2020-195

idsp: ljournal-02-2020-195

Abstract

The article is devoted to the study of social well-being and the construction of the structure of its study. Mechanisms have been developed for studying it through the 
supporting structure. Horizontal and vertical skeletons are filled with concrete content, how social processes are perceived by people and which feelings and moods dominate in people. To study social well-being, indicators have been developed by which we can further examine the social well-being of a person.

Keywords: social well-being, indicators of social well-being, referents, social reality, design, vertical frame, horizontal frame

In the modern, dynamically developing world, we need to consider when digitalizing the economy, expanding international relations and the social well-being of people. Often, success in solving the tasks depends on it. To this end, we have developed a mechanism for studying social well-being. The content and structure of social well-being can be interpreted in a certain system of their description and measurement.

This system can be expressed through the concept of the supporting construction of social well-being. The triad "social fact - social experience socio-psychological trail" acts as its vertical frame. It is quite obvious that the basis of social well-being is the complex attitude of people to the objective reality surrounding them. The system of various objective social facts (events and phenomena in the life and work of people) forms and makes up this social reality, which has an impact on society.

The socio-psychological attitude of people that arose on the basis of the perception of social reality gives rise to certain complex experiences that leave their mark in the social psyche of society in the form of a gamut of feelings and emotions: both positive (for example, satisfaction with one's life and activity), and negative (for example, when experiencing dissatisfaction with life and activity). This socio-psychological trail, on the one hand, is the result of social experiences, and on the other, it is reflected in the form of a specific social well-being of people. It is possible to diagnose social well-being both by the results of experiences and by their outcome. In the latter case, it is also necessary to analyze the social expectations and social positions (status) of people, satisfaction or dissatisfaction with them.

The horizontal "frame" of the supporting structure of social well-being is the "unity" of psychological times (the past is "social memory", the present is "awareness of this social reality", the future is "the image of the desired future: the purpose and meaning of life"), existence and manifestation of which quite well studied by psychologists at the moment. Moreover, it is the unity of psychological time that is ensured by the functioning of the mutually conditioning psychological, conscious, ideological and spiritual components of social consciousness.

2. The vertical and horizontal "frames" of the construction of social well-being serve as its skeleton, which allows it to be filled with specific content:

1) the perception and comprehension by people of social processes, their social expectations and their place in the system of social relations (social positions), as well as assessments of self-awareness as subjects of social activity (perceptual-evaluative component);

2) dominant feelings and moods in people; situational emotional states that ultimately determine the presence (absence) of satisfaction and confidence in one's life and activity (emotional component);

3) manifestations of people's readiness (unpreparedness) for certain actions to preserve or change their life and activity, level of social activity (behavioralmotivational component).

The collapse of vertical and horizontal connections (structures) in the supporting structure of social well-being leads either to the destruction of historical memory, characteristic of public consciousness, or disrupts the action of its entire mechanism. All this ultimately negatively affects all manifestations of the social psyche of people, in a certain way coloring their social experiences and social behavior, changing the overall well-being of the 
social subject, which is an indicator of the mental (mental) and spiritual health or ill health of society.

3. The substantial characteristics that allow you to measure social well-being, if you do not take into account its structural elements and the clear relationships of all its components, include:

social expectations and social claims that manifest themselves in attitudes, values, conviction and readiness for action. Values - these are generalized goals and means of achieving them, performing the role of fundamental norms. Their characteristics are directly related to the analysis of needs and interests, those preferences, expectations and claims of people that are most acceptable in a given situation. People's adherence to certain value attitudes, which are peculiar "concepts of what is desired," determines people's social wellbeing. Having a significant impact on people's perception of their objective position, value orientations act as a kind of prism, which determines a special angle of view and attitude to the changes that are taking place.

- $\quad$ assessment and self-esteem by people of their social status, social status, which is reflected in their ideas about social prestige, social role. All of them taken together largely determine the level of people's interest in maintaining or rejecting individual events, processes that affect them. It is with their help that the futility of the future is determined in case of dissatisfaction with the real social situation, which gives rise to a wide range of conditions состояний from apathy and indifference to deep feelings that can lead to uncontrolled behavior both in relation to society (violent methods of confrontation) and in relation to to ourselves and our neighbors (creating an unbearable environment in the immediate environment, conflicts and even suicide). The resulting indicator of social well-being in this case is the need for self-preservation of oneself as a social being, as a member of a group and society, as well as an assessment of the level and degree of well-being of the immediate surrounding social environment.

the sharpness of people's well-being, manifested in public opinion. Public opinion arises as a product of awareness of matured and problem-solving problems of economics, politics, culture and is manifested in a comparison of different views and positions on issues of interest to people. Depending on the approval, support or denial, condemnation of certain actions or events, social well-being can take on completely different meanings from positive to sharply negative,

social feelings and moods, the subject of which, first of all, are those phenomena and conditions on which the development of events that are significant for people and gaining an emotional effect due to this. With this formulation of the question, feelings and moods become leading formations of the emotional sphere of life and society and, in turn, often determine the dynamics and content of social well-being. Thus, the feeling of the Motherland, depending on specific circumstances, can give rise to feelings of pride for its greatness and achievements, frustration - for missed opportunities in the development of the country, anger and criticism - for gross mistakes that violate the honor and dignity of people, sympathy and empathy - for some inevitable losses and losses. Which ultimately affects the social well-being of both society as a whole and its specific representatives.

- the influence of historical memory, which, as real life shows, in modern conditions is crucial for determining the appropriate state of health of people, since the latter functions on the basis of social attitudes and social stereotypes that focus on experiencing historically and culturally fixed states of public consciousness.

4. The specifics of the content of social well-being is that it is an integral formation with a high degree of cumulativeness. Arising as a result of combining the manifestations of a certain complex of heterogeneous phenomena enclosed in a common construction, social well-being as an integral state of the psyche of people, on the one hand, cannot be described using one summary description. And on the other hand, it cannot be 
studied directly, therefore it has to be studied and interpreted through various manifestations in separate aspects of people's life and their subjective understanding. Social well-being as an integral state cannot be measured by any single indicator, and, therefore, it is necessary to study its individual components, describing each of them with a specific system of indicators.

5. In accordance with the above reasoning, it is possible to determine the real indicators (referents) of the manifestation of people's social well-being. These indicators are:

a) objective characteristics of the status of a person (profession, marital status, place in the system of social strata on the basis of material well-being, education, marital status);

b) a person's satisfaction with his position in society (in society, in the family, in his immediate environment); a person's attitude to his social responsibilities, to state values;

c) social attitudes and value orientations;

d) socio-political activity of a person; the real involvement of man in society;

e) the prevailing emotional state in a person (mood);

f) the degree of connectedness with society, the level of identification of oneself as a member of various social communities;

g) the dynamics of social well-being in the past and present;

h) confidence in the future and the availability of prospects for professional and personal growth.

In the final result, a comparison of these indicators with the parameters of manifestation of social well-being made it possible in turn to clarify and expand their number and variety. It turned out in the final result that they might look like this:

- $\quad$ by the parameter of social activity - the ability to influence the socio-political events taking place in the country; a split in the highest authorities as a significant problem for the respondent of modern Russia; non-reflection of the problems of modern Russia; degree of satisfaction with one's social activity; lack of opportunities for free, public expression of their political views and requirements and obtaining reliable information to form their own social position; the degree of accessibility of information about the social situation in society;

according to the parameter of financial situation - the correspondence of real income to actual needs; correspondence of remuneration to personal efforts and professional excellence; material well-being for loved ones as an urgent need; satisfaction with their financial, economic and material situation at the moment;

- $\quad$ according to the parameter of self-realization - the realization of one's abilities and personality development as an important value at the moment; level of achievement of life goals at the moment; the realization of one's potential as an individual; the desire to freely, publicly express their political views and demands as an urgent need; [3, P. 593].

- according to the parameter of labor activity - correspondence of salary to personal efforts and professional excellence; good work in their specialty as an urgent need; satisfaction with the distribution of wages in the team; satisfaction with the content of their work;

- $\quad$ according to the health parameter - satisfaction with the health care sector;

- according to the manifestations of the emotional-sensual sphere - the most typical mood at the moment; an idea of the mood of most people around; gaining confidence in the future as an important potential value;

- $\quad$ in the field of moral and aesthetic attitudes - behavior in accordance with their ideals; compliance of personal moral standards with the norms of a significant part of society; [2, p. 17].

in the field of marital status and relations - a good family as an important value at the moment; the ability to comply with the customs and traditions of their people as an urgent need; 
- $\quad$ in the field of leisure; енность satisfaction with opportunities for leisure;

- according to the parameters of social identification - pride in one's country; adoption of the values that dominate in modern Russian society; compliance with the customs and traditions of their people as an urgent need; real social identity with a specific society at the moment; [1, p. 186].

- according to the parameter of social comfort; - adoption of the values that dominate in modern Russian society; assessment of their social status in society; satisfaction with the comfort of living in society; satisfaction with the social security of oneself and one's loved ones;

- $\quad$ in the field of social and household arrangements - satisfaction with the medical services sector; characteristics;

according to the parameters of the manifestation of individual personality

- $\quad$ satisfaction with the productivity of life (i.e. with their self-realization in life, productivity and meaningfulness of life); locus of control-I (I am the master of life, a strong personality, building his life in accordance with his goals and ideas about its meaning); locus of control-life (controllability of life by the person himself, confidence in the ability to control his life, make decisions and bring them to life); externality in relation to health and illness.

In the end result, we got a tool for studying social well-being.

1. Simonovich N. E. Influence of the status and position of an individual on her social well-being In the collection: Training and development: modern theory and practice // Materials of the XVI International readings in memory of L. S. Vygotsky. 2015.S. 186 - 187.

2. N. Simonovich. Social well-being as a socio-psychological phenomenon in a changing Russian society. // Abstract of the dissertation of the candidate of psychological sciences // Moscow, 1999.

3. Simonovich N. E. Socio - psychological characteristics of students In the collection: Training and development: modern theory and practice // Materials of the XVI International readings in memory of L. S. Vygotsky. 2015.S. 592 - 594. 